\begin{tabular}{cc|c}
\hline Tar. Bil. Der. & Journal of Agricultural Sciences \\
& $\begin{array}{c}\text { Dergi web sayfası: } \\
\text { www.agri.ankara.edu.tr/dergi }\end{array}$ & Journal homepage: \\
& www.agri.ankara.edu.tr/journal
\end{tabular}

\title{
Genetic Analysis of Maize (Zea mays L.) Hybrids Using Microsatellite Markers
}

\author{
Eminur ELÇía, Tuğçe HANÇER ${ }^{\mathrm{a}}$ \\ a Biotechnology Department, Progen Seed Company, 31000, Antakya, Hatay, TURKEY
}

\section{ARTICLE INFO}

Research Article

DOI: 10.1501/Tarimbil_0000001321

Corresponding Author: Eminur ELÇI, E-mail: eminur@gmail.com, Tel: +90 (326) 2856700

Received: 15 March 2014, Received in Revised Form: 27 May 2014, Accepted: 05 June 2014

\begin{abstract}
Genetic purity is one of the most important quality criteria required for successful hybrid seed production. In this study, molecular markers were used for assessing the genetic purity and diversity of three commercially important maize $\mathrm{F}_{1}$ hybrids (Pasha, Frida and PG1661) and their parental inbred lines. Fifty Simple Sequence Repeats (SSRs) markers were used to analyze samples, also the efficiency of the markers were compared. Twenty three primer pairs among the fifty markers were able to detect polymorphism between the different types of hybrids with an average of 0.69 polymorphism information content (PIC) value. Genetic purity analyses revealed more than $98 \%$ homogeneity in the hybrid seeds. The hybrids were grouped into three main clusters. It can be concluded that, molecular markers are efficient to study the genetic purity and diversity in maize hybrids and microsatellites are more accurate marker-type because of their co-dominancy.

Keywords: Maize; Seed genetic purity; Genetic diversity; SSRs; Cluster analysis
\end{abstract}

\section{Mısır (Zea mays L.) Hibritlerinin Mikrosatellit İşaretleyiciler Kullanılarak Genetik Analizleri}

\section{ESER BILGISI}

Araştırma Makalesi

Sorumlu Yazar: Eminur ELÇİ, E-posta: eminur@gmail.com, Tel: +90 (326) 2856700

Geliş Tarihi: 15 Mart 2014, Düzeltmelerin Gelişi: 27 Mayıs 2014, Kabul: 05 Haziran 2014

\section{ÖZET}

Genetik saflık, hibrit tohum üretimi için gerekli olan önemli kalite kriterlerinden biridir. Bu çalışmada, moleküler işaretleyiciler ticari olarak önemli 3 mısır $\mathrm{F}_{1}$ hibrit çeşidi (Pasha, Frida ve PG1661) ve kendilenmiş saf ebeveyn hatlarının genetik saflık ve çeşitlilik analizleri için kullanılmıştır. Örnekler, elli adet basit dizi tekrarları (SSR) işaretleyicileri kullanılarak analiz edilmiş ve işaretleyicilerin verimliliği karşılaştırılmıştır. Testlenen 50 işaretleyici içinden 23 primer çifti ortalama 0.69 polimorfizm bilgisi değeri ile değişik hibrit çeşitleri arasındaki farklılığ tespit etmiştir. Hibrit tohumların genetik saflık analizi, \% 98'den yüksek homoloji oranı ile sonuçlanmıştır. Hibritler, 3 ana gruba toplamıştır. $\mathrm{Bu}$ çalışma ile moleküler işaretleyicilerin mısır hibritlerinin genetik saflık ve çeşitlilik analizleri için kullanılmasının verimli olduğu ve mikrosatellitlerin ko-dominantlık özellikleri nedeni ile doğru işaretleyiciler olduğu saptanmıştır.

Anahtar Kelimeler: Mısır; Tohum genetik saflı̆̆ı; Genetik çeşitlilik; SSRs; Küme analizi 


\section{Introduction}

Maize (Zea mays L.) is one of the most important cereal crops and has the highest production area worldwide followed by wheat and rice (FAO 2012). It can be consumed as boiled, roasted, vegetable directly by humans as well as being used for livestock feed. Maize cultivation has changed along with the revolution in genetics and maize breeding programs depend on characterization and genetic diversity among breeding material (i.e. inbred lines, hybrids, populations, landraces and races). Identification of genetically distant parental combinations provides best crop improvements for breeders. Also, it is essential to assess genetic purity of hybrids before seed marketing. Genetic purity is one of the quality criteria required for successful hybrid seed production.

Conventionally, purity of $F_{1}$ hybrids is assessed by grow-out test (GOT) at the field (Roos and Wianer, 1991). This test is time consuming and resource intensive. Also, it depends on morphological differences which are usually affected by environmental conditions. Isozyme analysis is an alternative method for seed purity testing but it is limited also by environmental conditions and requires accurate selection of isozymes (Lucchese et al 1999). Genetic purity can be determined based on agronomical, morphological, biochemical, and molecular analysis (Wang et al 1994; Dubreuil \& Charcosset 1998; Koranyi 1989; Srdic et al 2007). However, molecular markers have advantages because they show very detailed genetic differences and are not affected by environmental factors. They involve fast and the techniques are reproducible (Pejic et al 1998; Warburton et al 2002).

Molecular marker technology provides effective, fast, accurate and appropriate tool for crop improvement. DNA markers such as RFLP (Restriction Fragment Length Polymorphism),
SSR (Simple Sequence Repeats), CAPS (Cleaved Amplified Polymorphic Sequences), RAPD (Randomly Amplified Polymorphic DNA), ISSR (Inter Simple Sequence Repeats), AFLP (Amplified Fragment Length Polymorphism), SNPs (Single Nucleotide Polymorphisms) have been used for varietal identification, seed purity testing, genetic similarity analysis and marker-assisted selection of crops in many species (Ajmone-Marsan et al 1998; Bornet \& Branchard, 2001; Dangel et al 2001; Powell et al 1996; Mammadov et al 2010). SSRs, also known as microsatellites, are repeated sequences of DNA(Gül-İnce et al 2011) and they can easily detect both parental alleles because of their codominancy.

The objective of the present study was to evaluate genetic purity and diversity among maize hybrids and their parental inbred lines by using microsatellites. Also, SSR marker efficiency was analyzed for further studies on maize.

\section{Material and Methods}

\subsection{Plant materials}

Seeds of three maize $\mathrm{F}_{1}$ hybrids $c v$. Frida, Pasha and PG1661, that are of high commercial importance in Turkey, and their six parental inbred lines were examined in this study (Table 1). Ten seeds of each parental line were mixed and 94 seeds of each hybrid were used for genetic purity analysis. The seeds were randomly selected without bias.

\subsection{Genetic purity analysis}

A total of 50 SSR markers (Table 2) were screened to select the polymorphic markers. After parental survey of markers, the highly polymorphic ten markers were selected to analyze seed genetic purity of hybrids. The evaluated microsatellites were

Table 1- Agronomical characteristics of tested maize hybrids

Çizelge 1- Testlenen misır hibritlerinin tarımsal karakteristik özellikleri

\begin{tabular}{lllclc}
\hline Hybrids & Maturity & Plant height & Ear height & Grain colour & Cob colour \\
\hline PG1661 & 130 days & $280-300 \mathrm{~cm}$ & $120-125 \mathrm{~cm}$ & Yellow-orange & Red \\
Pasha & 125 days & $300-320 \mathrm{~cm}$ & $120-140 \mathrm{~cm}$ & Yellow-orange & Red \\
Frida & 120 days & $280-300 \mathrm{~cm}$ & $110-120 \mathrm{~cm}$ & Yellow-orange & Red \\
\hline
\end{tabular}

Tarım Bilimleri Dergisi - Journal of Agricultural Sciences 21 (2015) 192-198 
selected from maizeGDB website and the primers' information is given at Table 2 .

DNAs were extracted according to CTAB method (Doyle \& Doyle 1990). Seeds were homogenized by TissueLyser (Qiagen, Germany) and incubated at $65^{\circ} \mathrm{C}$ for $30 \mathrm{~min}$. in CTAB buffer $(2 \%$ CTAB; $1 \mathrm{M}$ Tris- $\mathrm{HCl}, \mathrm{pH} 7.5 ; 0.5 \mathrm{mM}$ EDTA, $\mathrm{pH} 8.0 ; 5 \mathrm{M}$ $\mathrm{NaCl} ; 2 \% \beta$-mercaptoethanol). After centrifugation of Chloroform-isoamylalcohol (24:1) added tubes, the supernatant was transferred into a new tube and cold isopropanol was added. DNA was washed and precipitated with ethanol and resuspended in $50 \mu \mathrm{L}$ TE buffer $\mathrm{pH} 8.0$ (0.1mMTris-HCl; $0.1 \mathrm{mM}$ EDTA). The quality and quantity of isolated DNAs were measured by NanoDrop Spectrophometer (ThermoScientific, USA). The selected DNAs were also used for cluster analysis.

After dilutions of DNAs, PCR was carried out with $2 \mu 1$ of DNA (50 ng ul-1), $0.5 \mu 1$ of $10 \mu \mathrm{M}$ dNTP, $1 \mu \mathrm{l}$ of $25 \mathrm{mM} \mathrm{MgCl} 2,2.5 \mu \mathrm{l}$ of $5 \mathrm{X}$ PCR buffer and $0.5 \mu \mathrm{l}$ of $10 \mu \mathrm{M}$ of each primers (Table 2) with $0.25 \mu 1$ of 500 units Taq DNA polymerase (Promega Corp., USA) Reactions incubated at 94 ${ }^{\circ} \mathrm{C}$ for 2 min and following 35 amplification cycles $\left(30 \mathrm{~s}\right.$ at $95{ }^{\circ} \mathrm{C}, 30 \mathrm{~s}$ at $50-60{ }^{\circ} \mathrm{C}$, and $30 \mathrm{~s}$ at 72 ${ }^{\circ} \mathrm{C}$ ) were performed. The final PCR products were visualized under UV light after electrophoresis on ethidium bromide-stained 2\% agarose gels. The genetic purity percentage was calculated with the following formula;
Seed Genetic Purity $(\%)=\left(1-\frac{\text { off }- \text { type }}{\text { total samples }}\right) \times 100 \%$

Polymorphism information content (PIC) values of molecular markers were calculated according to the following formula: $\mathrm{PIC}=1-\Sigma \mathrm{Pi}^{2}$. Where; $\mathrm{Pi}$ is the frequency of the $\mathrm{i}^{\text {th }}$ allele (Anderson et al 1993).

\subsection{Genetic diversity analysis}

The extracted DNAs of three $F_{1}$ hybrids and their six parental inbred lines, obtained from genetic purity test, were used for genetic diversity analysis. Twenty three polymorphic SSR markers were used for analysis (Table 3). After gel electrophoresis of PCR products, each band was considered as a single allele and alleles were scored as present (1) or absent (0). The matrix was analyzed to reconstruct phylogenetic tree using the Unweighted Pair Group Method Arithmetic Mean (UPGMA) on Numerical Taxonomy and Multivariate Analysis System (NTSyS-PC) program (Rohlf 2000).

\section{Results and Discussion}

Based on parental survey analysis using 50 SSR markers, twenty three markers located on ten different chromosomes of maize genome, were found highly polymorphic for both parents and hybrids of $c v$. Frida, Pasha and PG1661 with an average of 0.69 PIC value (Table 3). These selected markers were used for testing seed genetic purity and diversity analyses (Figure 1).

Table 2- Evaluated SSR Markers' information used for genetic analyses

Çizelge 2-Genetik analizler için değerlendirilen SSR işaretleyicilerinin bilgileri

\begin{tabular}{lc}
\hline Maize SSR markers* & Located chr. no. \\
\hline UMC 1363, UMC1976, UMC1395, UMC1358, UMC1111 & 1 \\
UMC 1265, UMC1465, UMC1004, UMC1108, UMC1604 & 2 \\
UMC 1970, UMC1425, UMC2002, UMC1135, UMC1273 & 3 \\
UMC 1228, UMC1963, UMC1117, UMC1109, UMC1707 & 4 \\
UMC 2291, UMC1587, UMC1060, UMC1155, UMC1072 & 5 \\
UMC 1143, UMC1133, UMC1857, UMC1413, UMC1859 & 6 \\
UMC 1241, UMC1159, UMC1134, UMC1708, UMC1407 & 7 \\
UMC 1327, UMC1913, UMC1858, UMC1268, UMC1638 & 8 \\
UMC 1370, UMC1809, UMC1191, UMC1231, UMC1137 & 9 \\
UMC 1380, UMC1962, UMC2016, UMC1115, UMC1196 & 10 \\
\hline
\end{tabular}

*, available at maizeGDB website 
Table 3- Primer sequences, band size and polymorphism information content (PIC) values of tested microsatellites

Çizelge 3- Testlenen mikrosatellitlerin primer dizisi, bant büyüklüğ̈̈ ve polimorfizm bilgisi

\begin{tabular}{|c|c|c|c|c|}
\hline Marker & F primer & $R$ primer & $\begin{array}{l}\text { No. of } \\
\text { bands }\end{array}$ & $\begin{array}{c}\text { PIC } \\
\text { values* }\end{array}$ \\
\hline UMC1363 & AAAGGCATTATGCTCACGTTGATT & TCTCCCTCCCCTGTACATGAATTA & 6 & 0.793 \\
\hline UMC1004 & CTGGGCATACAAAGCTCACA & TGCATAAACCGTTTCCACAA & 5 & 0.793 \\
\hline UMC2002 & TGACCTCAACTCAGAATGCTGTTG & ACAAAATCCTCGAGTTCTTGATT & & 0.768 \\
\hline UMC1963 & TCGTTCGAGGGGATGTACAAG & TTGCACTGGCACAGAGACG & & 0.693 \\
\hline UMC1117 & AATTCTAGTCCTGGGTCGGAACTC & CGTGGCCGTGGAGTCTACTACT & 6 & 0.793 \\
\hline UMC2291 & CTCGACGAGTTCAAGCGCTAC & AACTTCTCCTGGCGAGCATCT & 4 & 0.521 \\
\hline UMC1587 & ATGCGTCTTTCACAAAGCA] & CCTGG & 7 & 0.818 \\
\hline UMC1060 & ACAGGATTTGAGCTTCTGGACATT & GCCTCТCСТTCATCCTATTCAA & 7 & 0.867 \\
\hline & GATT & & 7 & 0.818 \\
\hline UMC1072 & GAGGAGACCGCCTCTGG & & 6 & 0.818 \\
\hline UMC1133 & ATTCGATCTAGGGTTTGGGTTCAG & GATGCAGTAGCATGCTGGATGTAG & 6 & 0.793 \\
\hline & & & & 0.867 \\
\hline UMC1859 & ATATACATGTGAGCTGGTTGCCCT & CTATTACCAATCTCCAGGT & 8 & 0.867 \\
\hline & & & & 0.644 \\
\hline & & & 5 & 0.521 \\
\hline UMC1327 & AGGGTTTTGCTCTTGGAATCTCTC & GAGGAAGGAGGAGGTC & 2 & 0.232 \\
\hline & ГСТCCTTGCTGACCAGTTT & & & \\
\hline & AGGTGACCTCGACGTCC & & 2 & 0.359 \\
\hline UMC1191 & AAGTCATTGCCCAAAGTGTTGC & ACTCATCACCССТCCAGAGTGTC & 3 & 0.570 \\
\hline & GGGAGCACACACAGTAGTACTCGAT & & & 0.855 \\
\hline UMC1962 & SGGGGAGGCGAGCTA & GAGAACCAACCACCAAAGAAGTCC & 6 & 0.793 \\
\hline & АCTACTGCTACAAAGCGA & AGTCGTTCGTGTCTTCCGAAACT & 4 & \\
\hline & CTGCTGATGTCTGGAAGAACCCT & AGCATCATGCCAGCAGGTTTT & 5 & 0.644 \\
\hline & & & & \\
\hline
\end{tabular}

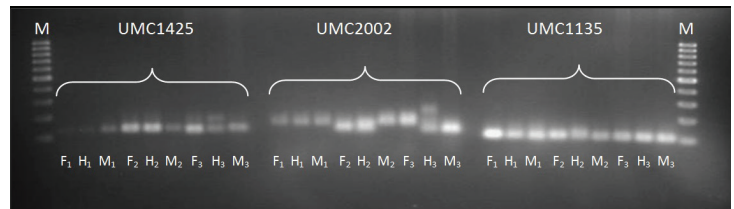

Figure 1- Parental survey analysis results of 3 maize hybrids, cv. Pasha, Frida, PG1661 and their parental inbred lines using 3 different SSR Markers (UMC1425, UMC2002, UMC1135). M, 100bp ladder (Fermentas); $\mathrm{F}_{1}$, female parent of $c v$. Pasha; $\mathrm{H}_{1}, c v$. Pasha; $\mathrm{M}_{1}$, male parent of $c v$. Pasha; $\mathrm{F}_{2}$, female parent of $c v$. Frida; $\mathrm{H}_{2}, c v$. Frida; $\mathrm{M}_{2}$, male parent of $c v$. Frida; $\mathrm{F}_{3}$, female parent of $c v$. PG1661; $\mathrm{H}_{3}, c v$. PG1661; $\mathrm{M}_{3}$, male parent of $c v$. PG1661

Şekil 1- Pasha, Frida ve PG1661 misir hibritleri ile ebeveyn hatlarının 3 farkl SSR işaretleyicisi (UMC1425, UMC2002, UMC1135) kullanilarak yapılan ebeveyn tarama analizi sonucu. $M, 100 b p$ ladder; $F_{l}$, Pasha'nin anne ebeveyni; $H_{l}, c v$. Pasha; $M_{1}$, Pasha'nin baba ebeveyni; $F_{2}$, Frida'nın anne ebeveyni; $H_{2}, c v$. Frida; $M_{2}$, Frida'nin baba ebeveyni; $F_{3}, P G 1661$ 'in anne ebeveyni; $H_{3}, c v . P G 1661 ; M_{3}$, PG1661'in baba ebeveyni

Out the 94 samples of $c v$. Pasha, two samples (sample 5 similar to parent A, sample 14 similar to parent B) were detected as off-type using UMC1858 and UMC1413 markers which detected most offtypes among the selected ten markers (UMC1004, UMC1587, UMC1060, UMC1155, UMC1858, UMC1191, UMC1962, UMC1371, UMC1413, UMC1380) (Figure 2). Two seeds of $c v$. Frida and one seed of $c v$. PG1661 out of 94 seeds were detected as off-types using UMC1191 marker (among UMC2002, UMC1963, UMC1117, UMC1363, UMC1859, UMC1638, UMC1858, UMC1191, 
UMC1196, UMC2291 markers) and UMC1155 markers (among UMC1004, UMC1963, UMC1060, UMC1155, UMC1133, UMC1241, UMC1638, UMC1371, UMC1196 markers), respectively. The confirmation of off-types detected by one marker with analysis by another marker indicated reliability of the test. According to seed genetic purity analysis of $c v$. Frida, Pasha and PG1661, it was detected that the tested hybrids have $97.8 \%, 97.8 \%$ and $98.9 \%$ seed homogeneity, respectively (Table 4). It is suspected that mixing occurred during pollination, harvesting or processing. Self-pollination of female parent is one of the main reasons for contamination in hybrid production. This is as result of incomplete removal of its tassel (Salgado et al 2006). Also, the purity level of parental inbred lines could affect the purity of their hybrids.

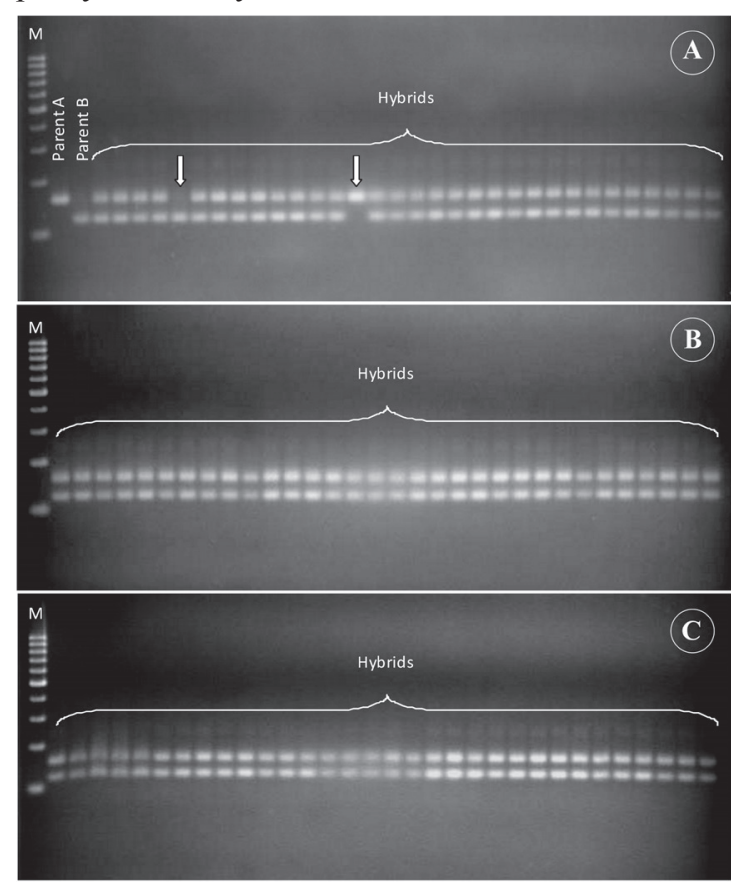

Figure 2- Agarose gel electrophoresis results of seed genetic purity testing of "Pasha" maize hybrids with their parents using UMC1858 primers. M, 100 bp ladder (Fermentas); arrows indicate off-types

Şekil 2- UMC1858 primerleri kullanılarak yapılan "Pasha" misir hibriti ve ebeveynlerinin tohum genetik saflk testinin agaroz jel elektroforezi sonucu; $M, 100$ bp ladder (Fermentas); oklar, tip-dışlarını göstermektedir
Table 4- The genetic purity analysis results of hybrid seeds $c v$. Frida, Pasha and PG1661 based on SSR analysis

Çizelge 4- SSR analizlerine göre; Frida, Pasha ve PG1661 hibrit çeşit tohumlarının genetik saflı analizi sonuçları

\begin{tabular}{lccc}
\hline Hybrids & $\begin{array}{c}\text { Number of } \\
\text { tested seeds }\end{array}$ & $\begin{array}{c}\text { Number of } \\
\text { off-types }\end{array}$ & $\begin{array}{c}\text { Genetic } \\
\text { purity (\%) }\end{array}$ \\
\hline PG1661 & 94 & 1 & 98.9 \\
Pasha & 94 & 2 & 97.8 \\
Frida & 94 & 2 & 97.8 \\
\hline
\end{tabular}

The cluster analysis based on genetic distance matrix obtained with UPGMA displayed 2 main groups with 2 subgroups (Figure 3). The hybrid $c v$. Pasha was clustered together with its parents in one group as expected. $c v$. PG1661 was clustered together with its male parent and parents of $c v$. Frida were clustered in the same group. The hybrid $c v$. Frida was detected genetically distant from their parents. The broad genetic diversity detected within the samples demonstrates the genetic purity and potentials of SSR markers for seed genetic purity analysis in maize.

Seed contamination is always a problem in hybrid seed production of maize. The SSR marker technology is currently used for purity identification in many crops. Microsatellite markers (phi96100, phi328175 and phi072) were reported highly polymorphic for genetic purity analysis of maize hybrids ( $c v$. Bima-3 and Bima-4) by Hipi et al (2013). Six SSR markers tested on maize hybrids and inbred lines were analyzed for genetic purity and diversity by Daniel et al (2012) and they were reported that these markers were powerful biotechnological tools capable of detecting genetic purity status of maize hybrids. Shehata et al (2009), showed the application of six SSR markers for molecular diversity and heterozygosity analysis in 8 different maize inbred lines. Also, Mingsheng et al (2006) were reported that SSR markers are useful for assessing genetic purity of maize hybrid, even if the hybrid derived from two related parental lines. All these studies confirm the efficiency of SSR markers in maize hybrid for seed genetic purity 


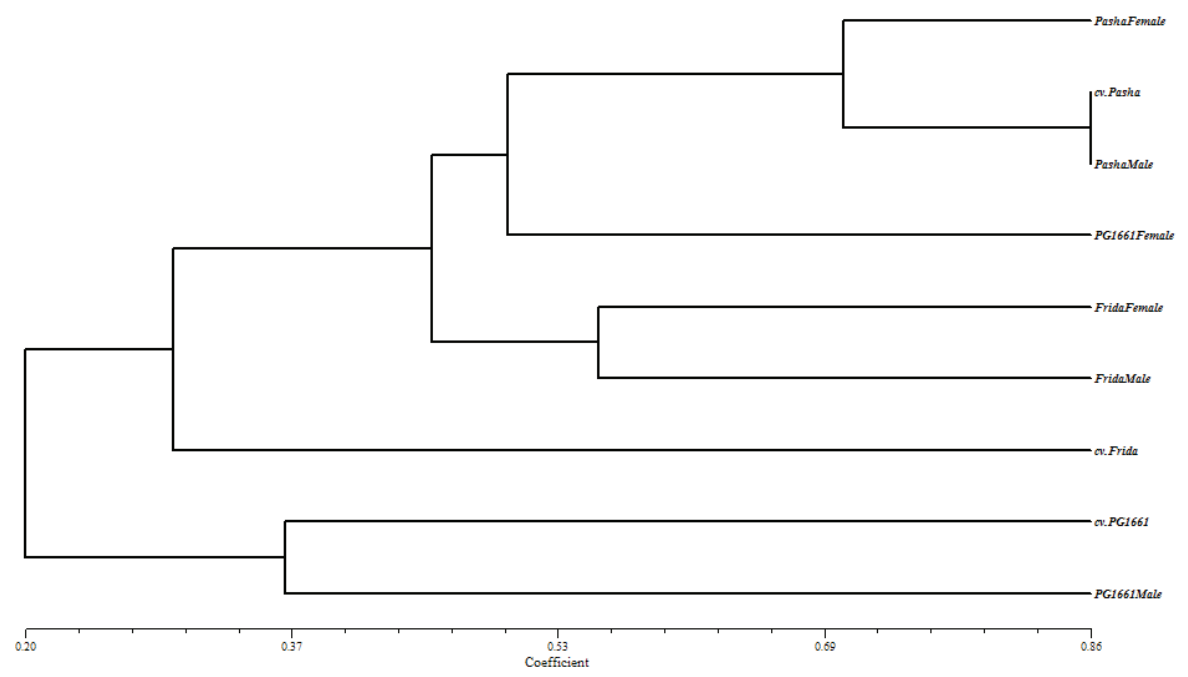

Figure 3- Dendrogram of the hybrids along with their inbred parents developed from SSR data

Şekil 3- Bu çalışmada kullanılan çeşitlerle ebeveynlerinin SSR verileri kullanılarak oluşturulan dendrogram

as indicated in our study. In this study, an efficient and precise method was established for rapid and reliable genetic purity testing of commercial maize hybrid seeds and genetic diversity of hybrids were determined.

\section{Conclusions}

It is concluded from this study that seed genetic purity analysis and differentiation of the maize hybrids, can be performed more accurately and efficiently using molecular markers. These molecular markers would be more efficient, fast and cheap than GOT. The SSR marker information developed through this study will be helpful for hybrid maize seed industry to select appropriate marker combinations and assess genetic purity of the crop.

\section{References}

Ajmone-Marsan P, Castiglioni P, Fusari F, Kuiper M \& Motto M (1998). Genetic diversity and its relationship to hybrid performance in maize as revealed by RFLP and AFLP markers. Theoretical and Applied Genetics 96: $219-227$
Anderson J A, Churchill G A \& Autrique J E (1993). Optimizing parental selection for genetic linkage maps. Genome 36: 181-186

Bornet B \& Branchard M (2001). Nonanchored inter simple sequence repeat (ISSR) markers: Reproducible and specific tools for genome fingerprinting. Plant Molecular Biology Reporter 19: 209-215

Dangle G A, Mendum M L, Prins B H, Walker M A, Meredith C P \& Simon C J (2001). Simple sequence repeat analysis of a clonally propagated species: a tool for managing a grape germplasm collection. Genomet 44: $432-438$

Daniel I O, Adetumbi J A, Oyelakin O O, Olakojo S A, Ajala M O \& Onagbesan S O (2012). Application of SSR markers for genetic purity analysis of parental inbred lines and some commercial hybrid maize (Zea mays L.). American Journal of Experimental Agriculture 2(4): 597-606

Doyle J J \& Doyle J L (1990). Isolation of plant DNA from fresh tissue. Focus 12: 13-15

Dubreuil P \& Charcosset A (1998). Genetic diversity within and among maize populations: A comparison between isozyme and nuclear RFLP loci. Theoretical and Applied Genetics 96: 577-587 
FAO (2012). Statistical database. Available at: http:// www.fao.org

Gül İnce A, Karaca M \& Onus A N (2011). Exact microsatellite density differences among capsicum tissues and development stages. Tarm Bilimleri Dergisi-Journal of Agricultural Sciences 17(4): 291299

Hipi A, Surahman M, Ilyas S \& Giyanto (2013). Seed genetic purity assessment of maize hybrid using microsatellite markers (SSR). International Journal of Applied Science and Technology 3(5): 66-71

Koranyi P (1989). Simple purity checking of maize lines and hybrids by protein monomer analysis. Seed Science and Technology 17: 161-168

Lucchese C, Dinelli G, Miggiano A \& Lovato (1999). Identification of pepper (Capsicum spp) cultivars by field and electrophoresis tests. Seed Science and Technology 27: 37-47

MaizeGDB (2013). Maize Genetics and Genomics Database. Available at: http:// http://www.maizegdb. org

Mammadov J A, Chen W, Ren R, Pai R, Marchione W, Yalçın F, Witsenboer H, Greene T W, Thompson S A \& Kumpatla S P (2010). Development of highly polymorphic SNP markers from the complexity reduced portion of maize [Zea mays L.] genome for use in marker-assisted breeding. Theoretical and Applied Genetics 121(3): 577-88

Mingsheng W, Xihai J, Lei T \& Baochun L (2006). Rapid and reliable purity identification of $F_{1}$ hybrids of maize (Zea mays L.) using SSR markers. Molecular Plant Breeding 4(3): 381-384

Pejic I, Ajmone-Marsan M, Morgante M, Kozumplick V, Castiglioni P, Taramino G \& Motto M (1998). Comparative analysis of genetic similarity among maize inbred lines detected by RFLPs, RAPDs, SSRs and AFLPs. Theoretical and Applied Genetics 97: 1248-1255

Powell W, Morgante M, Andre C, Hanagey M, Vogel J, Tingey S \& Rafalski A (1996). The comparison of RFLP, RAPD AFLP and SSR (microsatellite) markers for germplasm analysis. Molecular Breeding 2: 225238

Rohlf F J (2000). NTSYS-PC. Numerical Taxonomy and Multivariate Analysis System. Version 2.0 Exeter Software, Setaket, NewYork

Roos E E \& Wianer L E (1991). Seed testing and quality assurance. HortTechnology 11: 65-69

Salgado K C P C, Vieira M D G G C, Pinho E V R V, Guimaraes C T, Pinho R G V \& Sousa R G V (2006). Genetic purity certificate in seeds of hybrid maize using molecular markers. Revista Brasileira de Sementes 28(1): 169-175

Shehata A I, Al-Ghethar H A \& Al-Homaidan A A (2009). Application of simple sequence repeat (SSR) markers for molecular diversity and heterozygosity analysis in maize inbred lines. Saudi Journal of Biological Sciences 16: 57-62

Srdic J, Mladenovic Drinic S, Pajic Z \& Filipovic M (2007). Characterization of maize inbred lines based on molecular markers, heterosis and pedigree data. Genetika 39(3): 355-363

Wang C, Bian K, Zhang H, Zhou Z \& Wang J (1994). Polyacrylamide gel electrophoresis of salt soluble proteins for maize variety identification and genetic purity assessment. Seed Science and Technology 22: 51-57

Warburton M L, Zianchun X, Crossa J, Frnaco J, Melchinger A E, Frisch M, Bohn M \& Hoisington D (2002). Genetic characterization of CIMMYT inbred maize lines and open pollinated populations using large scale fingerprinting methods. Crop Science 42: 1832-1840 